\title{
International comparative study of $3 R$ and waste management policy developments
}

\author{
Shin-ichi Sakai • Hideto Yoshida • Yasuhiro Hirai • Misuzu Asari • \\ Hidetaka Takigami - Shin Takahashi $\cdot$ Keijirou Tomoda $\cdot$ Maria Victoria Peeler • \\ Jakub Wejchert • Thomas Schmid-Unterseh • Aldo Ravazzi Douvan • \\ Roy Hathaway • Lars D. Hylander • Christian Fischer • Gil Jong Oh • \\ Li Jinhui • Ngo Kim Chi
}

Received: 25 May 2010/Accepted: 7 February 2011/Published online: 18 May 2011

(C) The Author(s) 2011. This article is published with open access at Springerlink.com

\begin{abstract}
Reduce, reuse, and recycle (3R) policies form the basis of waste management and global warming countermeasures globally, so we conducted a comparative study of $3 \mathrm{R}$ and waste management policies in the European Union (EU), USA, Korea, Japan, China, and Vietnam.
\end{abstract}

The views expressed herein are those of the authors and not necessarily the official view of the organizations with which the authors are affiliated.

S. Sakai $(\bowtie) \cdot$ Y. Hirai · M. Asari

Environment Preservation Research Center, Kyoto University,

Kyoto 606-8501, Japan

e-mail: sakai@eprc.kyoto-u.ac.jp

H. Yoshida

Japan Environmental Safety Corporation, Tokyo, Japan

H. Takigami

Research Center for Material Cycles and Waste Management, National Institute for Environmental Studies, Tsukuba, Japan

\section{S. Takahashi}

Center for Marine Environmental Studies, Ehime University,

Matsuyama, Japan

K. Tomoda

Towa Technology, Hiroshima, Japan

M. V. Peeler

Hazardous Waste and Toxics Reduction, Washington State

Department of Ecology, Olympia, WA, USA

J. Wejchert

Sector in Unit G.4, Sustainable Production and Consumption, DG Environment, European Commission, Brussels, Belgium

T. Schmid-Unterseh

Division of Product Responsibility, Avoidance, Recovery and

Utilization of Product Waste, Federal Ministry for the

Environment, Berlin, Germany
An international workshop for 3R and waste management policymakers was held in Kyoto, Japan, and a bibliographic survey was also conducted to collect data. 3R policies are clearly given priority in the hierarchy of waste management in every country studied. Thermal recovery,
A. R. Douvan

Italian Environmental Authority for EU Structural Funds, Ministry for the Environment Land and Sea, Rome, Italy

\section{R. Hathaway}

Waste Management Division, Department of Environment, Food and Rural Affairs, London, UK

L. D. Hylander

Department of Earth Sciences, Air and Water Science,

Uppsala University, Uppsala, Sweden

\section{Fischer}

European Topic Centre on Sustainable Consumption and Production, Copenhagen, Denmark

G. J. Oh

Resource Recirculation Center, National Institute of Environmental Research, Incheon, Korea

L. Jinhui

Department of Environmental Science and Engineering, Tsinghua University, Beijing, China

N. K. Chi

Union for Scientific Research and Production on Chemical Engineering, Vietnam Academy of Science and Technology (VAST), Hanoi, Vietnam 
which includes power generation from waste heat and methane gas collected from organic waste, is also a priority; this is consistent with the increased use of countermeasures to reduce greenhouse gas (GHG) emissions. In the EU, waste management is characterized by practical and effective $3 \mathrm{R}$ policies through the development of realistic regulations and by the policymakers' desire to simplify management systems. The policy ideal in China, however, is the development of a circular economy that targets reductions in the amount and hazardousness of waste. Limits on the number of final disposal sites, strategies for procuring resources, and GHG emission countermeasures are closely linked with $3 \mathrm{R}$ policies, and further development of $3 \mathrm{R}$ policies in parallel with such issues is expected.

Keywords 3R - Recycling · Waste management . International comparison $\cdot$ Policy developments

\section{Introduction}

It is generally recognized that reduce, reuse, and recycle (3R) and waste management policies form the basis of developing a material cycles society. However, $3 R$ and waste management policies differ among countries owing to each country's particular circumstances or political strategies. In this study, therefore, our aim was to compare the current situation, historical background, and effectiveness of $3 \mathrm{R}$ policies within one region [the European Union (EU)] and five countries (USA, Korea, Japan, China, and Vietnam). The characteristics and effectiveness of $3 \mathrm{R}$ policies in each country and within the EU are examined, and the future directions of developments for a material cycles society are discussed.

\section{Methods}

The Kyoto workshop on 3R and waste management was held in Kyoto, Japan, on 29-30 October 2009. The aim was to collect comparative data on institutional schemes of $3 \mathrm{R}$ and waste management. The participants were policymakers and researchers from the European Commission, Germany, England, Italy, Denmark, Sweden, USA, Korea, China, Vietnam, and Japan. EU Member States are generally considered to have developed integrated and advanced waste management systems, whereas Asian countries have been importing recyclable resources in recent years, essentially playing the role of global recycling facilities. Given these circumstances, the purpose of the workshop was to compare and discuss $3 \mathrm{R}$ and waste management policies in these different regions and to clarify their characteristics and effectiveness. As a means of collecting more information, copies of Japan's national report on 3R and waste management were distributed to participants in advance and similar reports were obtained from participating countries. In addition, a field survey was carried out in several countries to confirm the condition of treatment facilities and waste management systems and to better understand the countries' policies and their effectiveness.

\section{Results and discussion}

Trends in $3 R$ and waste management policies

\section{Characteristics and constitution of waste management policies}

Table 1 shows the waste management policy frameworks in the EU and the five countries. Driven by global environmental problems and the depletion of natural resources, the major focus of waste management policies changed during the late twentieth and early twenty-first centuries. Formerly, the focus was on promoting environmentally sound waste treatment to avoid local environmental pollution, whereas policies have shifted to pursue the concept of sustainability by introducing and promoting $3 \mathrm{R}$ policies.

USA Enactment of the Resource Conservation and Recovery Act (RCRA, significantly amended in 1984), Pollution Prevention Act (amended in 2002), and Resource Conservation Challenge (2004) has led to the development of a waste management policy centering on resource conservation and pollution prevention in the USA. The RCRA states the fundamental principles for the treatment of solid waste and for the reduction and management of hazardous wastes, but municipal solid waste (MSW) is managed under the regulations of each state.

Under the Pollution Prevention Act, the 2010-2014 Strategic Plan is currently being drawn up. According to a draft, the purposes of the plan are to (1) reduce greenhouse gas (GHG) emissions, (2) reduce the manufacture and use of hazardous substances, (3) decrease the use of water, (4) create effective business activities, and (5) develop institutions and integrate established practices for pollution protection. The draft also states that achievement of the first four goals will result in co-benefits [1].

The Resource Conservation Challenge is a program complementary to the RCRA and Pollution Prevention Act. It aims to prevent pollution and promote reuse and recycling, reduce the use of hazardous chemicals, and conserve energy and resources. Its action plan sets MSW recycling targets [2].

The US Environmental Protection Agency (EPA) is also currently working on amending the EPA Strategic Plan. According to the draft, they will shift the political priority 
Table 1 Waste management frameworks

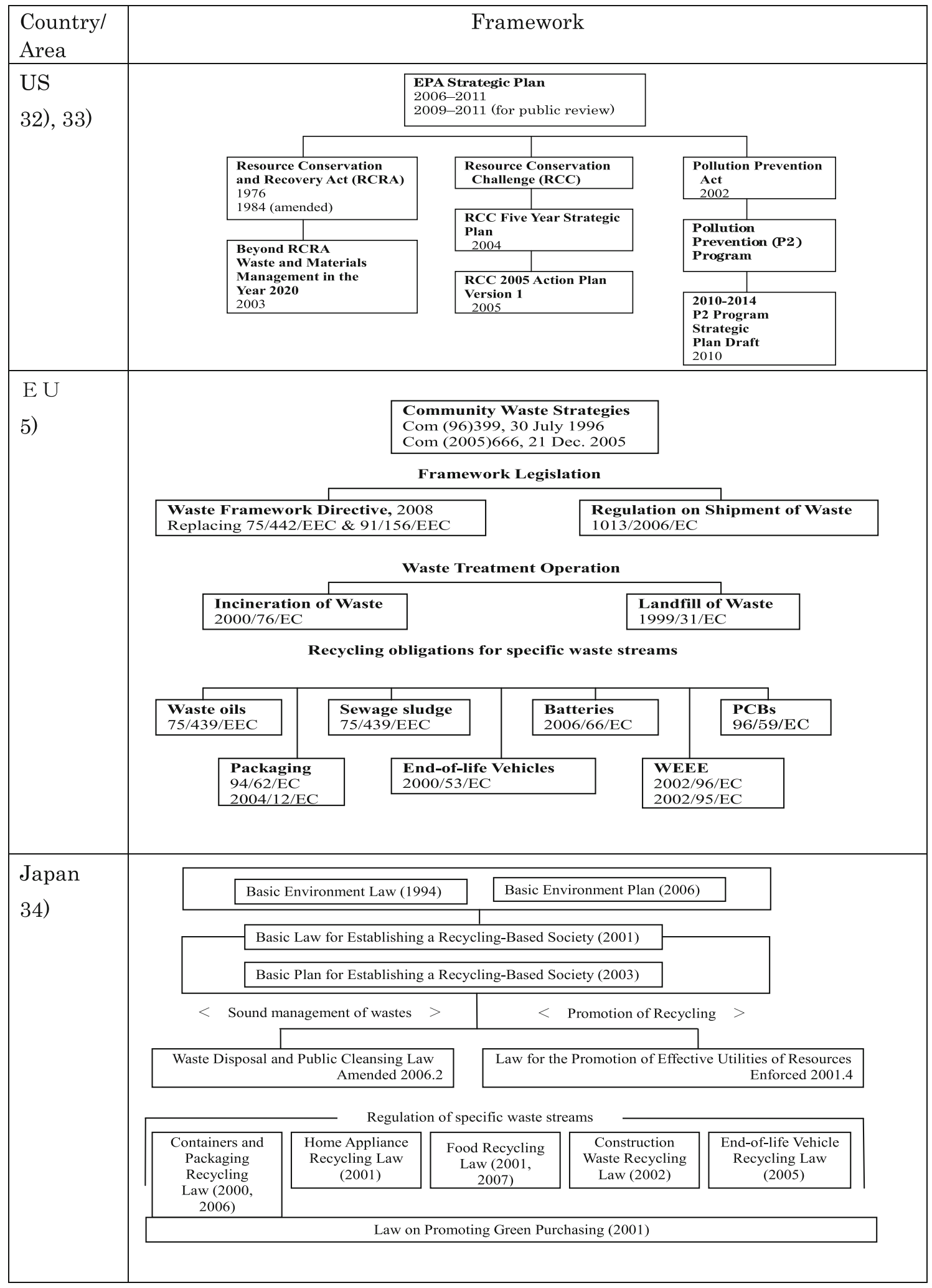


Table 1 continued

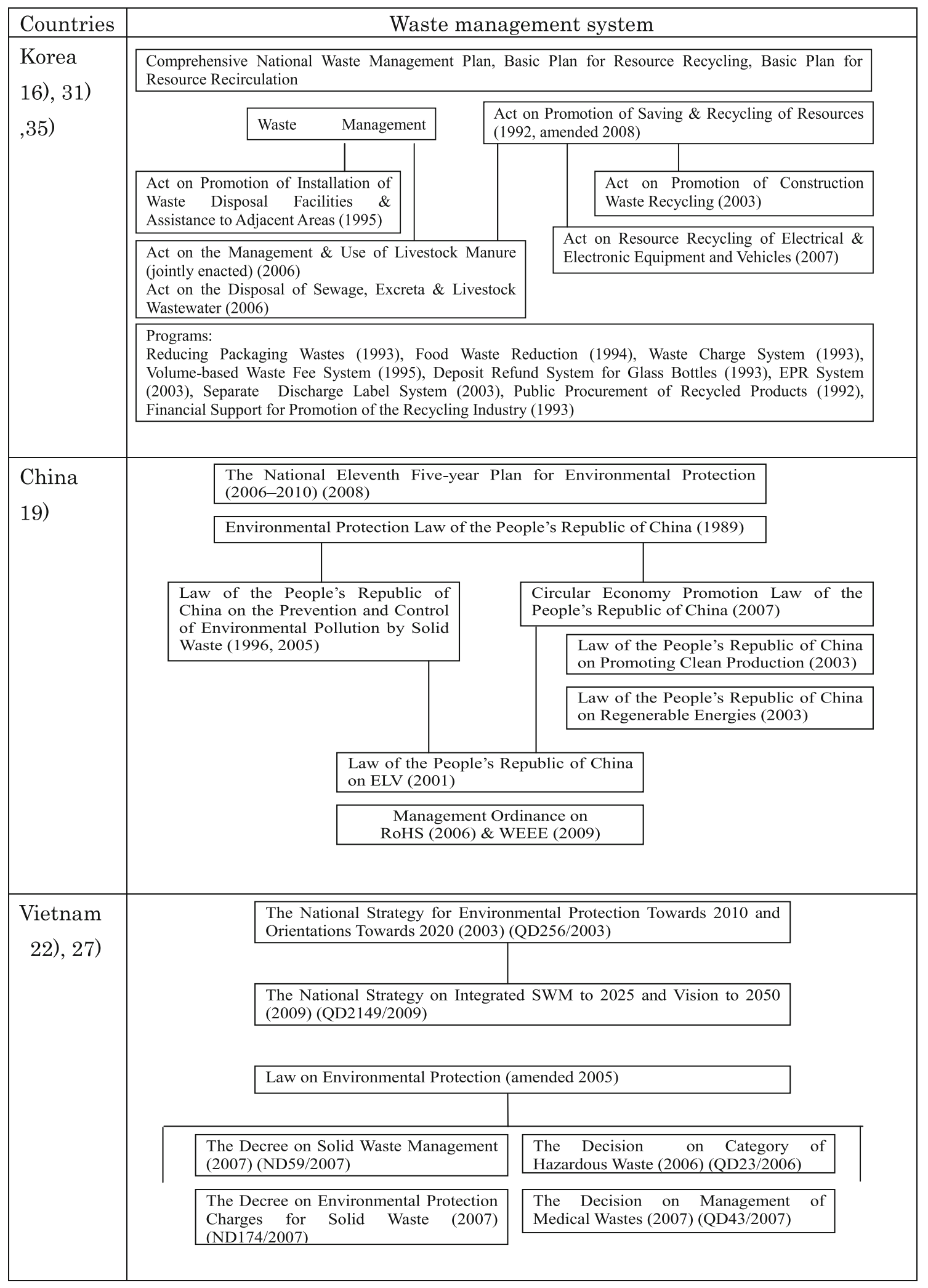


from waste management to resource management as a strategy to reduce GHG emissions [3].

Waste management policy in the USA is currently integrated and includes measures to reduce GHG emissions, manage hazardous chemicals, and conserve natural resources.

$E U$ In the EU, the Waste Framework Directive (2008) [4] has been established as the basic waste management legislation, and EU Member States have implemented domestic laws on waste management under this directive. The most notable characteristic of the EU's waste management system is the promotion of $3 \mathrm{R}$ policies in parallel with waste management regulations. The Directive on the Incineration of Waste (2000) and the Directive on the Landfill of Waste (1999) concern waste management. The Directive on the Incineration of Waste primarily sets standards for the application of best available techniques/ best environmental practice (BAT/BEP) for environmental conservation, and it has had a notable effect in reducing dioxin emissions. The Directive on the Landfill of Waste sets standards for a tiered reduction of the disposal of wastes containing organic materials at final disposal sites (i.e., landfills). To reduce the amount of wastes for final disposal, the directive has promoted the introduction of $3 \mathrm{R}$ policies [5, 6]. The Directive on Waste Electrical and Electronic Equipment (WEEE) and the Directive on Restriction of Hazardous Substances (RoHS) were established in 2002 for the purpose of promoting sound material recycling and preventing pollution from the hazardous chemicals contained in such wastes. WEEE recycling has been promoted through the introduction and use of WEEE collection points. The extended producer responsibility (EPR), which requires that a producer of products manages them through reuse, recycling, and disposal even after their useful life and must develop and produce products that are easy to reuse and recycle, was applied to the basic concepts for the development of 3R policies for WEEE and packaging. Germany was the first country within the EU to apply EPR to packaging waste, in 1992 [7], and that was followed by legislation on collecting and recycling of endof-life vehicles (ELV) and waste batteries.

Although EPR is recognized as an important concept in the UK, its waste management policy is based on the principle of shared responsibility which presupposes that the responsibility for production of a product, circulation, consumption, disposal, and recycling is shared by everyone [8]. The government has signed a voluntary agreement with industry to reduce wastes and promote recycling of packaging materials, food, and paper. The UK introduced a landfill tax, which is currently $40 \mathrm{GBP} / \mathrm{t}$ and will increase by $8 \mathrm{GBP}$ annually to $72 \mathrm{GBP} / \mathrm{t}$ in 2013 . Italy has introduced economic measures through a unit-based fee system whereby a management fee in paid according to the quantity of waste to discharge to encourage better waste management, and about $15 \%$ of municipalities, or $29 \%$ of Italy's population, currently are covered by this type of system [9].

Japan The basic law for establishing a Material Cycles Society (2000) defines recyclable resources and states the principles for their utilization [10]. The law has the goal of a society wherein the consumption of natural resources is restrained and the environmental load is reduced as far as possible, through promotion of the $3 \mathrm{R}$ as well as the environmentally sound waste management. The law set quantitative targets for three indicators: resource productivity, cyclical use rate, and final disposal amount. These goals have also been pursued on a global scale through the Group of Eight (G8) process known as the 3R initiative. The basic legislation concerning waste management in Japan consists of the Waste Disposal and Public Cleansing Law (amended in 2010), which is the basic law of waste management, and the Law for the Promotion of Effective Utilities of Resources (2001), which is the basic law for recycling of used resources. The laws for recycling specific items such as containers and packaging, WEEE, food waste, construction waste, and ELV were established in these laws. In addition, the Law on Promoting Green Purchasing was enacted in 2001, with the purpose of promoting government procurement of recycled products. Japan's waste management system is characterized by the existence of two independent basic acts on waste management as well as on material recycling, under which the laws concerning recycling of specific items are laid down. The legislative framework is similar to those of the EU and Korea.

Korea The basic legislative framework on waste management in Korea consists of the Waste Management Act (amended in 2007) and the Act on Promotion of Resources Saving and Recycling (amended in 2008) [11]. The full-text amendment of the Waste Management Act was implemented in 1991 to introduce waste recycling, a deposit system, and standards for incineration and landfill [12]. The Act on Promotion of Resources Saving and Recycling is a revision of the Act on Promotion of Resource Recycling enacted in 2002, and it lays out the basic plan for material reuse, the fee system for waste treatment, regulations on the use of one-way packaging and goods, and EPR [13]. EPR was also included in the Act on Resource Recycling of Electrical and Electronic Equipment and Vehicles, which was enacted in 2008 [14].

The initial driving force for the promotion of $3 \mathrm{R}$ policies in Korea was a strong campaign by neighborhoods against the construction of waste treatment facilities [14]. The Promotion of Installation of Waste Disposal Facilities and Assistance to Adjacent Areas Act [15] was enacted in 1995 to ensure that facilities were adequately established. At the 
same time, a fee system for waste generation was introduced as a strict economic measure against increases in the amount of waste, in addition to other measures such as separated collection and regulations on the use of one-way packaging. From 2005, organic wastes were no longer accepted at landfills and had to be recycled [16].

China The basic environmental legislation in China is the Environmental Protection Law of the People's Republic of China (1989), under which other laws were established. The Environmental Pollution Prevention and Control Law by Solid Waste was enacted in 1996 and amended in 2005. It introduced the application of $3 R$ policies for solid municipal, industrial, and hazardous wastes and required not only a reduction in the amount of waste but also in its hazardousness [17]. Treatment consists mainly of detoxification of wastes, but the law does not establish a priority in terms of treatment methods (e.g., incineration or landfill). The inventory on hazardous wastes was also established in this act.

The Circular Economy Promotion Law, enacted in 2008, is the basic law concerning material cycles and waste management in China [18]. Several factors are said to be behind the enactment of the Circular Economy Promotion Law, including a lack of resources, insufficient use of recycled materials, and a national strategy of tackling the problem of resource depletion, accompanied by the desire for sustainable economic growth. In other words, the substantial lack of resources in the face of a rapidly growing economy caused China to expand its use of recycled materials. At the same time, China's economic growth was accompanied by a massive increase in the amount of waste generated; this produced serious social and environmental problems and an urgent need to improve China's waste management systems. Consequently, the integrated use of recycled resources and the promotion of zero emissions at production facilities were considered to be essential, especially in the circular economic zone where many industrial facilities are located. The Circular Economy Promotion Law thus emphasizes the promotion and management of $3 \mathrm{R}$ activities in the industrial sector and includes economic incentives, such as a reduction in, or exemption from, the value-added tax, for the integrated and circulative use of resources [19].

In order for the Circular Economy Promotion Law to have substantive effects, WEEE and MSW management systems needed to be enhanced through improving recycling and waste treatment techniques and strengthening the financial base of companies utilizing recycled resources. Although the focus of waste management policies in China has been on the problem of resource depletion and maintaining rapid economic growth, the environmental protection system with regard to imported recycling materials also needed improvements. Furthermore, measures also had to be taken against increased MSW caused by population expansion and economic development in urban areas. To this end, the ELV Recycling Law (2001) and Management Ordinance on WEEE (2009) were established [19]. The production of automobiles is increasing dramatically in China and is predicted to result in a massive increase in ELV in the near future. Nevertheless, rather than ensuring sound waste management of ELV, the ELV Recycling Law emphasizes the prevention of illegal remodeling, ensures car safety, and promotes the purchase of new models with environmentally friendly features. Furthermore, existing recycling facilities lack the capacity to meet the predicted demand for ELV recycling [20, 21].

Vietnam The basic legislation for environmental management in Vietnam is the Environmental Protection Law (amended in 2005), which takes precedence over other laws concerning waste management. The waste management system was established under the Decree on Solid Waste Management (2007), which establishes environmental protection measures for solid waste treatment [22]. The Decree covers the overall waste management policy and prioritizes recycling, reutilization, and treatment and recovery, to prevent land consumption by landfills [23]. The collection, transport, and treatment of waste are subject to fees of 40,000 VND/t for MSW and as much as $6,000,000 \mathrm{VND} / \mathrm{t}$ for hazardous wastes [24]. Hazardous and medical waste categories are defined under the decision [25, 26]. The former regulation on the control of hazardous wastes (decision no. 155/1999/QD) was incorporated in the Decree regulations on solid waste management as articles $70-75$ at the time of its amendment.

The targets for waste management in Vietnam are determined under The National Strategy on Integrated SWM for the years of 2025 and 2050 (2009) [27]. The midterm strategic targets for 2025 are to have separated MSW. Solid wastes from business activities in urban areas and hazardous and non-hazardous wastes from industrial sectors are to be managed completely $(100 \%)$ in an environmentally sound manner, and $90 \%$ of all construction wastes in urban areas and municipal solid wastes in the suburbs are to be collected. In addition, the strategy calls for minimizing the amount of final disposal by 2050 through the collection of all solid wastes, promotion of $3 \mathrm{R}$ policies, and employment of advanced and environmentally sound techniques. In Vietnam's case, the incentive for the promotion of $3 \mathrm{R}$ activities in urban areas seems to arise from a sense of crisis about the upcoming depletion of land available for use as landfills [28].

\section{Waste management targets}

The EU and other countries employ a common hierarchical approach in their $3 \mathrm{R}$ and waste management 
Table 2 Recycling targets in the USA [2, 32]

\begin{tabular}{|c|c|c|c|c|c|c|c|c|}
\hline \multicolumn{6}{|l|}{2001 MSW } & \multicolumn{3}{|c|}{ Proposed 2008 recovery goals } \\
\hline & $\begin{array}{l}\text { Generation } \\
(\mathrm{Mt})\end{array}$ & $\begin{array}{l}\text { Generation rate }{ }^{\mathrm{a}} \\
(\%)\end{array}$ & $\begin{array}{l}\text { Recovery } \\
\text { (Mt) }\end{array}$ & $\begin{array}{l}\text { Recovery rate } \\
(\%)\end{array}$ & $\%$ & Mt & $\begin{array}{l}\text { Increase } \\
(\%)\end{array}$ & $\begin{array}{l}\text { Increase } \\
\text { (Mt) }\end{array}$ \\
\hline \multicolumn{9}{|l|}{ Organic waste } \\
\hline Food, other & 26.2 & 11.4 & 0.7 & 2.8 & 5 & 1.28 & 2.2 & 0.58 \\
\hline Yard waste & 28.0 & 12.2 & 15.8 & 56.5 & 60 & 16.8 & 3.5 & 1.0 \\
\hline \multicolumn{9}{|l|}{ Paper } \\
\hline $\begin{array}{l}\text { Paper and paperboard } \\
\text { products }\end{array}$ & 81.85 & 37.2 & 36.7 & 44.9 & 53.8 & 44.1 & 8.9 & 7.32 \\
\hline \multicolumn{9}{|l|}{ Packaging and containers } \\
\hline Wood packaging & 8.17 & 3.6 & 1.25 & 15 & 24 & 2 & 9.2 & 0.75 \\
\hline Plastic wrap & 2.58 & 1.1 & 0.17 & 6.6 & 19 & 0.5 & 12.8 & 0.33 \\
\hline Beverage containers & 11.3 & 5.0 & 2.93 & 26 & 39 & 4.36 & 12.7 & 1.43 \\
\hline Total & 158.1 & 68.9 & 57.55 & 36.4 & 43.7 & 69.04 & 7.3 & 11.5 \\
\hline
\end{tabular}

Other targets were to maintain the national average MSW generation rate at not more than $4.5 \mathrm{lb}$ (about $2 \mathrm{~kg}$ ) per person per day each year through 2008; and to increase recycling rate of the total annual MSW produced to 35\% in 2008 from $31 \%$ in 2002

Mt million ton

${ }^{a}$ Generation rate; Generation $(\mathrm{Mt}) /$ the total $2001 \mathrm{MSW}$ generation $(229.2 \mathrm{Mt}) \times 100$

Table 3 Waste management targets in the EU [30]

\begin{tabular}{|c|c|c|c|c|}
\hline Targeted products & $\begin{array}{l}\text { Targeted } \\
\text { period }\end{array}$ & Min. recovery & Min. recycling & Collection rate \\
\hline Packaging & 2008 & $60 \%$ & $55 \%$ & \\
\hline Cars & 2015 & $95 \%$ & $85 \%$ & $100 \%$ \\
\hline Electronics & 2006 & $70 \%$ & $50 \%$ & Min, $4 \mathrm{~kg}$ per inhabitant per year \\
\hline \multirow[t]{3}{*}{ Batteries } & 2011 & & $50-75 \%$ & \\
\hline & 2012 & & & $25 \%$ \\
\hline & 2016 & & & $45 \%$ \\
\hline Tires & 2006 & Zero landfill of & tires & \\
\hline \multirow[t]{3}{*}{ Biowaste diverted from landfills } & 2006 & Reduction to 7 & $5 \%$ of the 1995 level & \\
\hline & 2009 & Reduction to 5 & $0 \%$ of the 1995 level & \\
\hline & 2016 & Reduction to 3 & $5 \%$ of the 1995 level & \\
\hline New targets & 2015 & Separate collec & tion of paper, metal, plastic, and glass & \\
\hline \multirow[t]{2}{*}{ Waste framework directive } & 2020 & & $50 \%$ of household waste & \\
\hline & 2020 & & $70 \%$ of construction and demolition waste & \\
\hline
\end{tabular}

Table 4 Waste management targets in Japan [10, 37]

\begin{tabular}{llll}
\hline & $\begin{array}{l}\text { Fiscal year 2000 } \\
\text { (base year) }\end{array}$ & $\begin{array}{l}\text { Fiscal year 2006 } \\
\text { (performance) }\end{array}$ & $\begin{array}{l}\text { Fiscal year 2015 } \\
\text { (target) }\end{array}$ \\
\hline Resource productivity & 260,000 yen/t & 350,000 yen/t & 420,000 yen/t \\
Circulation use ratio & $10 \%$ & $12.5 \%$ & $14-15 \%$ \\
MSW, per person per day (decrease) & $1,185 \mathrm{~g}$ & $1,116 \mathrm{~g}(-5.8 \%)$ & $1,070 \mathrm{~g}(-10 \%)$ \\
Household waste, per person per day (decrease) & $654 \mathrm{~g}$ & $601 \mathrm{~g}(-8.1 \%)$ & $520 \mathrm{~g}(-20 \%)$ \\
MSW from business sectors & $17.99 \mathrm{Mt}$ & $15.82 \mathrm{Mt}(-8.1 \%)$ & $14.40 \mathrm{Mt}(-20 \%)$ \\
Recycling amount (increase) & $5.9 \mathrm{Mt}(\sim 11 \%)$ & $10 \mathrm{Mt}(\sim 20 \%)$ & $12 \mathrm{Mt}(\sim 24 \%)$ \\
Final disposal & $56 \mathrm{Mt}$ & $29 \mathrm{Mt}$ & $23 \mathrm{Mt}$ \\
\hline
\end{tabular}


Table 5 Recycling targets for individual items in Japan [10]

\begin{tabular}{|c|c|c|c|c|}
\hline Classification & Item & $\begin{array}{l}\text { Target rate } \\
(\%)\end{array}$ & Definition of target & $\begin{array}{l}\text { Target fiscal } \\
\text { year }\end{array}$ \\
\hline \multirow[t]{8}{*}{ Containers and packaging } & Glass bottles & 91 & $\begin{array}{l}\text { Percentage of cullet use relative to the amount of } \\
\text { glass bottles manufactured in Japan }\end{array}$ & 2010 \\
\hline & PET bottles & - & - & - \\
\hline & $\begin{array}{l}\text { Plastics containers and } \\
\text { packaging }\end{array}$ & - & - & - \\
\hline & $\begin{array}{l}\text { Paper containers and } \\
\text { packaging }\end{array}$ & - & - & - \\
\hline & Steel cans & - & - & - \\
\hline & Aluminum cans & - & - & - \\
\hline & Paper cartons & - & - & - \\
\hline & Cardboard & - & - & - \\
\hline Paper & & 62 & $\begin{array}{l}\text { Percentage of recycled paper use relative to the } \\
\text { amount of paper manufactured in Japan }\end{array}$ & 2010 \\
\hline \multirow[t]{5}{*}{ Home appliances } & Air conditioners & 70 & Recycling/disposal & - \\
\hline & Cathode-ray tube TVs & 55 & Same as above & - \\
\hline & Refrigerators and freezers & 60 & Same as above & - \\
\hline & Washing machines & 65 & Same as above & - \\
\hline & $\begin{array}{l}\text { Liquid-crystal TVs, } \\
\text { plasma TVs }\end{array}$ & 50 & Same as above & \\
\hline \multirow[t]{3}{*}{ Construction waste } & $\begin{array}{l}\text { Asphalt and concrete } \\
\text { lumps }\end{array}$ & 98 & $\begin{array}{l}\text { Percentage of recycled material weight relative to } \\
\text { the weight of specific construction waste }\end{array}$ & 2012 \\
\hline & Concrete lumps & 98 & Same as above & 2012 \\
\hline & $\begin{array}{l}\text { Construction waste } \\
\text { timber }\end{array}$ & 95 & Same as above & 2012 \\
\hline \multirow[t]{4}{*}{ Food waste } & Food manufacturers & 85 & $\begin{array}{l}{[(\text { Generating prevention amount })+(\text { recycling }} \\
\text { amount })+(\text { heat recovery } \\
\text { amount }) \times 0.95+(\text { treatment amount })] / \\
{[(\text { generating prevention amount })+(\text { generating }} \\
\text { amount })]\end{array}$ & - \\
\hline & Food retailers & 45 & Same as above & - \\
\hline & Food wholesale business & 70 & Same as above & - \\
\hline & Food service industry & 40 & Same as above & - \\
\hline \multirow{4}{*}{$\begin{array}{l}\text { Personal computers and } \\
\text { peripherals devices }\end{array}$} & Desktop computers & 50 & Resource recycling/recovered & - \\
\hline & $\begin{array}{l}\text { Notebook personal } \\
\text { computers }\end{array}$ & 20 & Same as above & - \\
\hline & Cathode-ray tube displays & 55 & Same as above & - \\
\hline & Liquid crystal displays & 55 & Same as above & - \\
\hline \multirow[t]{4}{*}{ Small, secondary batteries } & Nickel-cadmium batteries & 60 & Recycling/disposal & - \\
\hline & Nickel-hydride batteries & 55 & Same as above & - \\
\hline & Lithium batteries & 30 & Same as above & - \\
\hline & Sealed lead acid batteries & 50 & Same as above & - \\
\hline
\end{tabular}

PET poly(ethylene terephthalate)

policies. However, there are also unique approaches within the various countries. For example, in China, where the concept of the circular economy is promoted as a policy ideal, Article 3 of the Solid Waste Pollution Prevention and Control Law clearly states that reduction (the first priority in the 3R management hierarchy) should be achieved not only in the amount of wastes but also in the waste's level of hazardousness [29]. The EU's waste management system is characterized by concerns about the practicality and effectiveness of its $3 \mathrm{R}$ policies, the development of a realistic legal framework, and the underlying attitude of policymakers toward simplifying the bewildering expansion of waste management systems [30]. 
Table $63 \mathrm{R}$ policy targets in Korea $[16,31]$

\begin{tabular}{|c|c|c|c|c|}
\hline \multicolumn{5}{|l|}{ Municipal waste management goals } \\
\hline Category & 2005 & 2008 & 2010 & 2012 \\
\hline Expected generation (t/day) & & 48,003 & 47,989 & 47,975 \\
\hline Reduction rate relative to 2005 & & $2.5 \%$ & $4.2 \%$ & $5.8 \%$ \\
\hline Waste generation (t/day) & 48,398 & 46,083 & 45,990 & 45,177 \\
\hline Recycling amount (t/day) & 27,243 & 26,678 & 27,134 & 27,558 \\
\hline Recycling rate (wt\%) & 56.3 & 57.0 & 59.0 & 61.0 \\
\hline
\end{tabular}

\begin{tabular}{lll}
\hline Regulations on packaging methods & & \\
\hline Category & Ratio of total packing size $(\%)$ & Number of packing layers \\
\hline Food stuffs & $10-20$ & $\leq 2$ \\
Cosmetics & $<10$ & $\leq 2$ \\
Detergents & $<10$ & $\leq 2$ \\
Sundries & $30-35$ & $\leq 2$ \\
Quasi-drugs & $<10$ & $\leq 2$ \\
Miscellaneous products & $<20$ & $\leq 2$ \\
\hline
\end{tabular}

Annual reduction targets for synthetic resin packaging materials

\begin{tabular}{ll}
\hline Item & Ratio of synthetic resin packages $(\%)$ \\
\hline Egg holders & $<40$ \\
Apple and pear holders & $<65$ \\
Instant noodle containers & $<85$ \\
Agricultural, livestock, and fishery products & $<90$ \\
Electrical appliances & ESP packaging for items under $20,000 \mathrm{~cm}^{3}$ in volume is prohibited
\end{tabular}

Target recycling rates

\begin{tabular}{ll}
\hline Item & Target rate $(\%)$ \\
\hline Used paper & 72 \\
Used glass & 71 \\
Used glass bottles & 50 \\
Used steel cans & 65 \\
\hline
\end{tabular}

Most of the countries are also setting concrete quantitative targets. The waste management targets are summarized in Table 2 (for the USA), Table 3 (the EU), Tables 4 and 5 (Japan), and Table 6 (Korea). A new waste management strategy is currently being drawn up in the USA, so the targets in Table 2 may soon be subject to revision.

Waste management targets serve as the progress benchmarks of $3 \mathrm{R}$ policies, and the targets are determined at the same time as the waste management hierarchy. The targets for reduction of overall wastes have the highest priority, followed by the targets for specific recycled items and targets for specific waste management measures.

The USA, Japan, and Korea all set targets for waste generation. In the USA, the maximum target for waste generation, which was to be achieved by 2008, is
$4.5 \mathrm{lb}$ person $^{-1} \mathrm{day}^{-1}$ or approximately $2 \mathrm{~kg}$ person $^{-1} \mathrm{day}^{-1}$ [2]. The target is under revision and discussion. In Japan, the target for non-industrial waste generation in 2015 is 1,070 , or $520 \mathrm{~g} \mathrm{person}^{-1} \mathrm{day}^{-1}$ for household solid waste [10]. If achieved, these targets would bring about a $10 \%$ (total MSW) and 20\% (household waste) reduction relative to the base year of 2000 for the USA and Japan, respectively. In Korea, however, the reduction rate relative to the estimated MSW amount in the target year is applied as a target index. The MSW amount of waste for 2012 is estimated to be $47,975 \mathrm{t} / \mathrm{day}$, and the reduction target is 45,177 t/day or $5.8 \%$ [31].

Targets for waste management measures are also used in the USA, EU, Japan, and Korea. In the USA, the target recycling rate in 2008 was $35 \mathrm{wt} \%$, relative to $31 \mathrm{wt} \%$ in 2002 [2]. In terms of the amount of material recovery, this 
Table 7 Breakdown of MSW management methods in each country

\begin{tabular}{llccl}
\hline Countries & Recycling & Incineration & Landfill & Total \\
\hline USA $^{\mathrm{a}}$ & $268(33.2)$ & $102(12.7)$ & $438(54.1)$ & $808(100.0)$ \\
$\mathrm{EU}^{\mathrm{b}}$ & $215(41.0)$ & $102(19.5)$ & $207(39.5)$ & $524(100.0)$ \\
$\mathrm{Japan}^{\mathrm{c}}$ & $100(25.1)$ & $290(72.6)$ & $9(2.3)$ & $399(100.0)$ \\
Korea $^{\mathrm{d}}$ & $221(57.8)$ & $71(18.6)$ & $90(23.6)$ & $382(100.0)$
\end{tabular}

Data are presented as in $\mathrm{kg}_{\text {person }}^{-1}$ year $^{-1}(\%)$

a 2008 data; incineration, only with energy recovery [36, 40]

b 2008 data [41]

c 2007 data; landfill, not including residue [42]

d 2007 data [43]

represents an increase from 57.55 million ton (Mt) in 2001 to $69.04 \mathrm{Mt}$ in 2008. In the 2010-2014 Strategic Plan, which is currently being revised, the target amount of $3 \mathrm{R}$ materials increases by approximately $58 \mathrm{Mt}$ by 2014 [1]. The EU determined that separation and collection should be deployed by 2015 for paper, metals, plastics, and glass, and it set the long-term recycling target at $50 \mathrm{wt} \%$ of household waste to be recycled by 2020 . The EU also aims to gradually reduce the amount of total household-generated waste containing organic material in landfills $(75 \%$ in $2006,50 \%$ in 2009 , and $35 \%$ in 2016) [30]. In Japan, the recycling target is $12 \mathrm{Mt}$ (24 wt\% of waste generation), and the target for final disposal is $23 \mathrm{Mt}$ ( $41 \%$ relative to the base year of 2000) [10]. In Korea, the recycling target for 2012 is $27,558 \mathrm{t} /$ day (10 Mt/year), or $61.0 \mathrm{wt} \%$ of total waste generated [31].

The USA, EU, and Korea also set recycling targets for packaging materials. In the USA, the target recovery amount for each material is defined, and the rate of recovery is calculated relative to the amount of each material as waste in the base year 2001 [2]. The target rates of recovery are $24.2 \%(+9.2 \%)$ for wooden packaging, $19.4 \%(+12.8 \%)$ for plastics, and $38.7 \%(+12.7 \%)$ for drinks packaging. It is likely that thermal methods are not regarded during the calculation of recovery rates in the USA. In the EU, the targets for material recycling and the targets for recovery, including heat utilization, are defined relative to the waste amount generated in the base year [30]. The material recycling target is $55 \mathrm{wt} \%$, whereas the target rate of recovery is $60 \%$. In Korea, the recycling target for each material is set yearly; in 2008 it was $50 \mathrm{wt} \%$ for glass and $65 \mathrm{wt} \%$ for steel cans [16]. The Korean performance report shows that the recycling rates for glass bottles, aluminum cans, and steel cans exceed $75 \mathrm{wt} \%$ [31]; thus, the target recycling rates may be subject to amendment. In addition, quantitative targets have also been set for reducing the use of packaging materials, and the selection of materials is also regulated [16].
Comparison of the effectiveness of $3 \mathrm{R}$ and waste management policies

\section{Waste generation and treatment measures}

Tables 7 and 8 show the amounts of waste generated and the methods (recycling, incineration, and landfill) used to treat MSW in the EU, USA, Japan, and Korea. Figure 1 shows the distribution of the management methods. In Japan, the total amount of landfilled materials includes incinerated materials that have gone through shredding and sorting processes at treatment facilities, recycled materials, and final disposal materials, including incinerated residues. Thus, for comparison, the amount recycled in Japan was calculated as (amount of waste generated) - (directly incinerated amount + direct landfilled amount); this was also done for data from the EU, although the calculated quantities are greater than the amounts in published data. Furthermore, although thermal recovery is not included in recycling in the USA, EU, and Korea, it is included in recycling in Japan.

The USA has the highest rate of waste generation $\left(800 \mathrm{~kg}\right.$ person $^{-1}$ year $\left.^{-1}\right)$, followed by Japan and Korea (both around $400 \mathrm{~kg}$ person ${ }^{-1}$ year $^{-1}$ ). In terms of MSW composition in the USA, the most dominant component is packaging, which accounts for $30 \%$, followed by waste containing organic materials (27\%), paper (24\%), and steel and plastics (18\%; percentage by weight in 2008) [38].

Waste management methods are quite different in Japan from in the EU and the other countries. Waste incineration predominates in Japan and the rate of final disposal in landfills is extremely low, whereas the rate of incineration is usually low elsewhere (Table 7; Fig. 1). There are also differences among the EU, USA, and Korea. The landfill rate in the USA and the EU reaches about $40-50 \%$ of the total amount of waste generated, but it is only about $20 \%$ in Korea. Korea also has a much higher recycling rate (almost $60 \mathrm{wt} \%$ ) than the EU and USA (about 30-40 wt\%). The yearly changes in management methods shown in Table 8 indicate that changes have been relatively gradual in the USA, whereas the landfill rates have drastically decreased as the recycling rates have increased in the EU, Japan, and especially in Korea.

Recycling rates in 2007 were highest in Korea (58 wt\%), followed by the EU (41 wt\%), USA (33 wt\%), and Japan (25 wt\%) (Fig. 2). The rate of recycling in Korea increased rapidly since restrictions were imposed on disposing of organic waste in 2005. In Korean statistics, separated and collected organic waste is counted as recycled waste [39]. The ratio of organic waste to total recycled waste was $45 \mathrm{wt} \%$ in 2008, indicating that almost half of recycling material is organic waste. However, although the organic waste is currently subject to composting and utilization as 
Table 8 Amount and ratio of MSW generated (per person per year) by waste treatment method in the USA [36, 40], EU [41], Japan [42], and Korea [43]

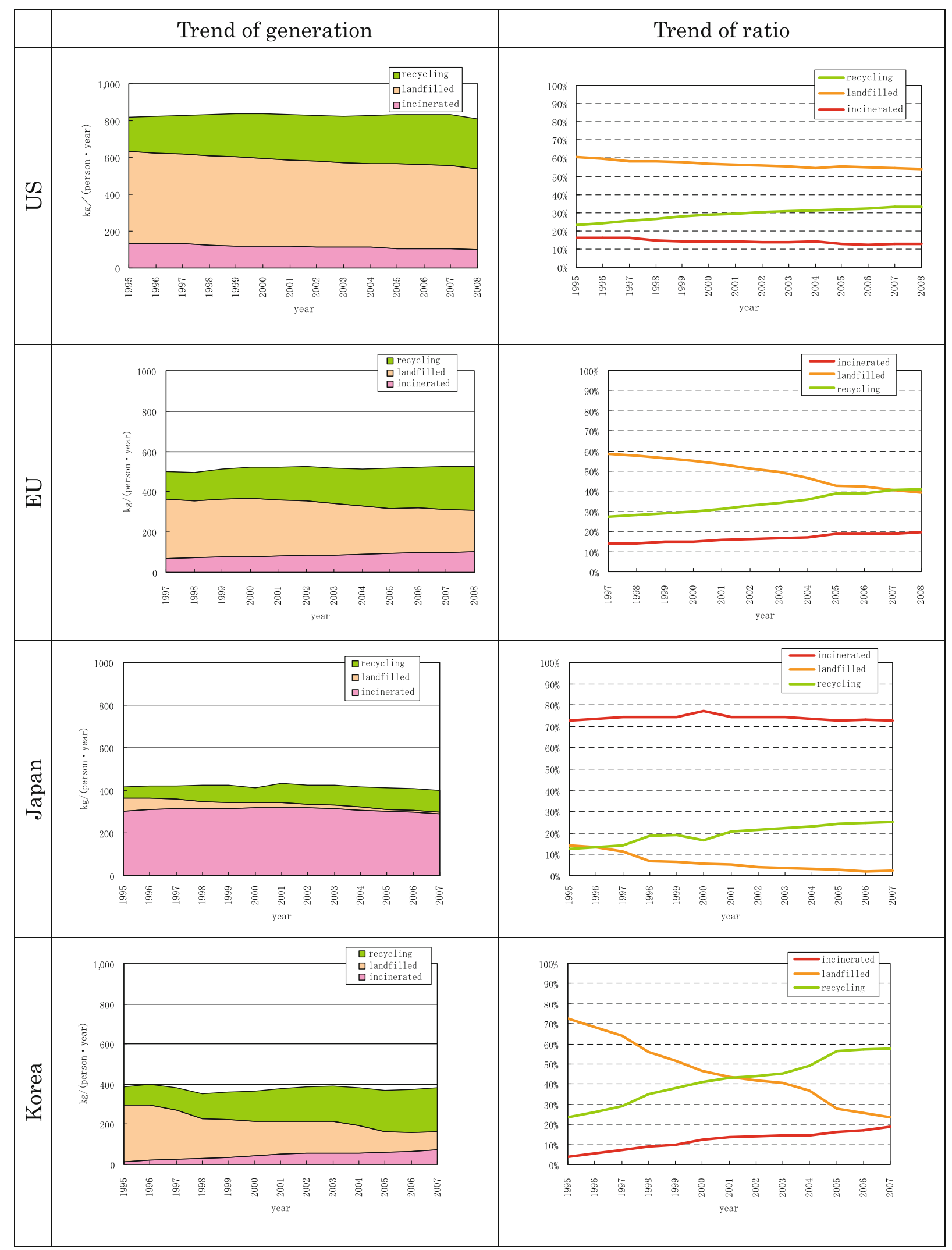




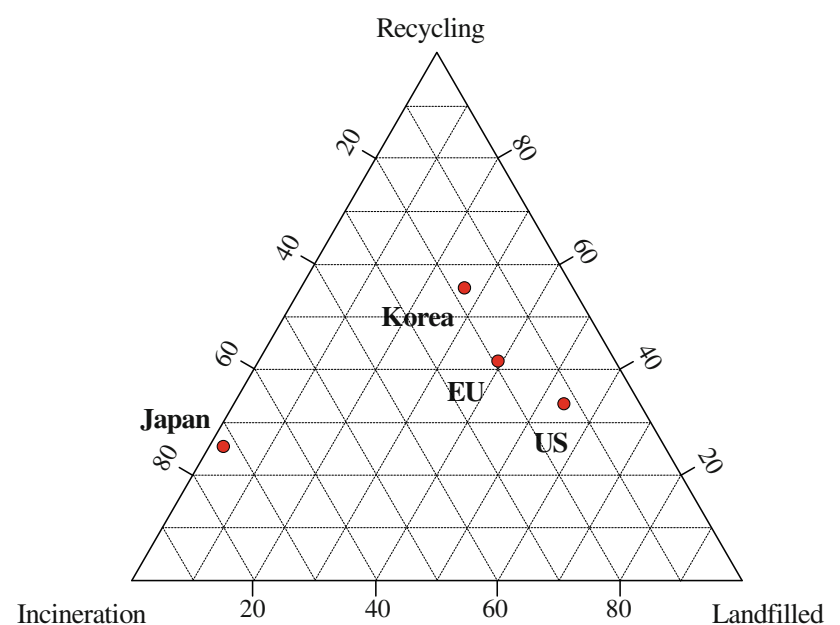

Fig. 1 Distribution of the rates of incineration, recycling, and landfilling in the USA [36, 40], EU [41], Japan [42], and Korea [43]

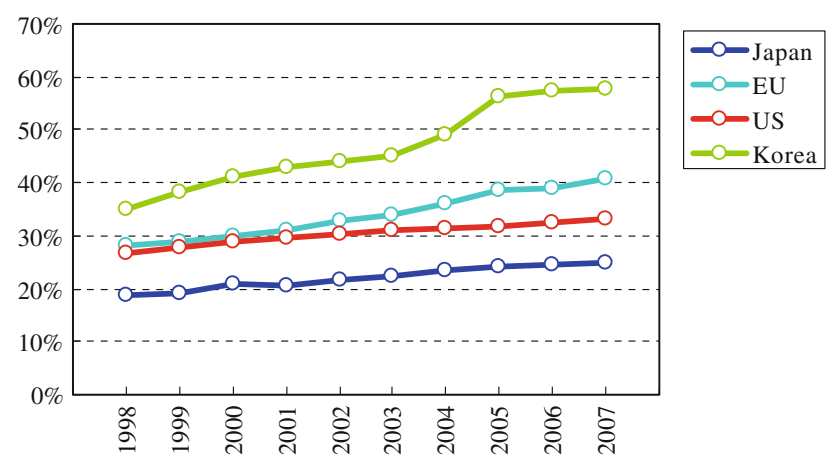

Fig. 2 Recycling rates in the USA [36, 40], EU [41], Japan [42], and Korea [43]

feed, there are still technical and economic problems with the use of organic waste [31]. Similarly, disposing of organic waste in landfills is prevented by law in the EU; this may have resulted in a higher recycling rate. In the USA, the rate of recycling refers mainly to paper and garden organic waste. In Japan, the rate of recycling refers mainly to paper and packaging waste. One reason for a low recycling rate is that the recycling of organic waste is not quite advanced enough.

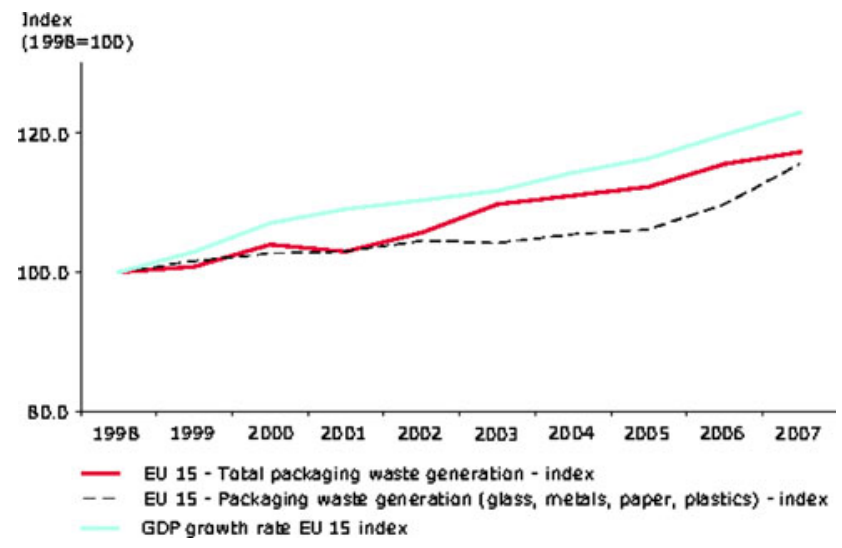

Fig. 3 Generation ratios of containers and of total packaging in the EU (15 member states) $(1998=100)[47]$

\section{Policies on recycling packaging materials}

Data on the recycling of packaging materials in the USA, EU, and Japan are shown in Table 9. There are differences among the scope of packaging materials collected in these countries. In the USA, the categories are glass, paper (corrugated cardboard boxes, milk containers, collapsible boxes, other bags, and packaging), metals (steel and aluminum cans), plastics [poly(ethylene terephthalate) (PET) bottles, high-density polyethylene, low-density polyethylene, and others], and wooden packaging $[36,40]$. In the $\mathrm{EU}$, the categories are glass, plastic packaging, paper packaging, and wooden packaging [44]. In Japan, the categories are glass, steel cans, aluminum cans, food trays, PET bottles, drinks boxes, corrugated cardboard, and other paper and plastic packaging [10]. In Japan and the EU, the categories are clarified in detail because the burden of the expense for collection and recycling falls on industry, whereas in the USA, the targets for recycling rate of packaging and containers are set by federal government, but collection systems are developed by each state or local government rather than at the federal level [45].

The recycling rate of packaging materials (the amount of recycled packaging as a proportion of total packaging waste generated, or $\mathrm{C} / \mathrm{B}$ in Table 9) is highest in the EU at $58.8 \mathrm{wt} \%$. The EU also has mandatory regulations and clear recycling targets. The rate is lowest in Japan

Table 9 Current generation and recycling of waste containers and packaging and basic recycling policy in the USA, EU, and Japan

\begin{tabular}{llcc}
\hline Categories & USA [36, 40] & EU [44] & Japan [42, 46] \\
\hline A: Total MSW generation (kg person ${ }^{-1}$ year $^{-1}$ ) & 808 & 524 & 399 \\
B: Packaging waste generation (kg person year $^{-1}$ ) & 249 & 165 & 93 \\
C: Recycled packaging production $\left(\mathrm{kg} \mathrm{person}^{-1}\right.$ year $\left.^{-1}\right)$ & 109 & 97 & 22 \\
Recycling rate (C/A) (wt\%) & 13.5 & 18.5 & 5.5 \\
Recycling rate (C/B) (wt\%) & 43.8 & 58.8 & 23.7 \\
\hline
\end{tabular}




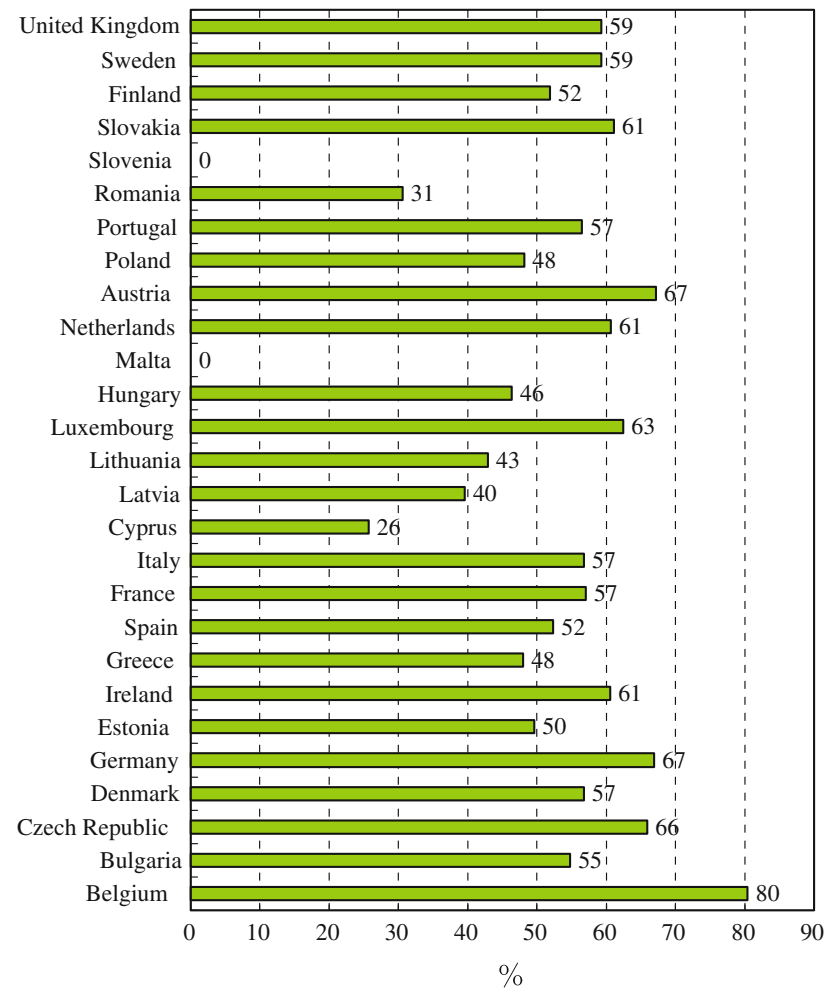

Fig. 4 Recycling rates for containers and packaging in the EU (in $\mathrm{kg}$ person $^{-1}$ year $^{-1}$ ) [44]

(23.7 wt \%), which has a legal recycling system but no clear targets for recycling. The US rate $(43.8 \mathrm{wt} \%)$ is closer to that of the EU.

The USA generates the greatest amount of packaging waste per person (249 $\mathrm{kg}_{\text {person }}^{-1}$ year $\left.^{-1}\right), 1.5-2$ times the amounts in the EU (165 kg person ${ }^{-1}$ year $\left.^{-1}\right)$ and Japan (93 $\mathrm{kg}$ person $^{-1}$ year $^{-1}$ ). In the EU, despite the early development of recycling specifically aimed at reducing packaging waste, the generation of packaging waste has increased (Fig. 3). There are also great differences among the rates of packaging recycling in these countries (Fig. 4). The existing recycling systems may have targets that are clearly enough defined for the reduction of waste packaging materials [5].

Promotion of packaging waste reduction and a mandatory recycling system have been implemented at several stages in Korea, including product design, sale, and collection and recycling. Under the EPR, introduction of mandatory recycling (including of tires and WEEE) by businesses is under way. In addition, reduction in the use of packaging is currently promoted by restrictions on the size of product packaging and by the use of a deposit system. Although public data on the rate of packaging recycling in Korea are not available, we estimated the amount of packaging recycling to be $41.7 \mathrm{~kg}$ person $^{-1}$ year $^{-1}$,

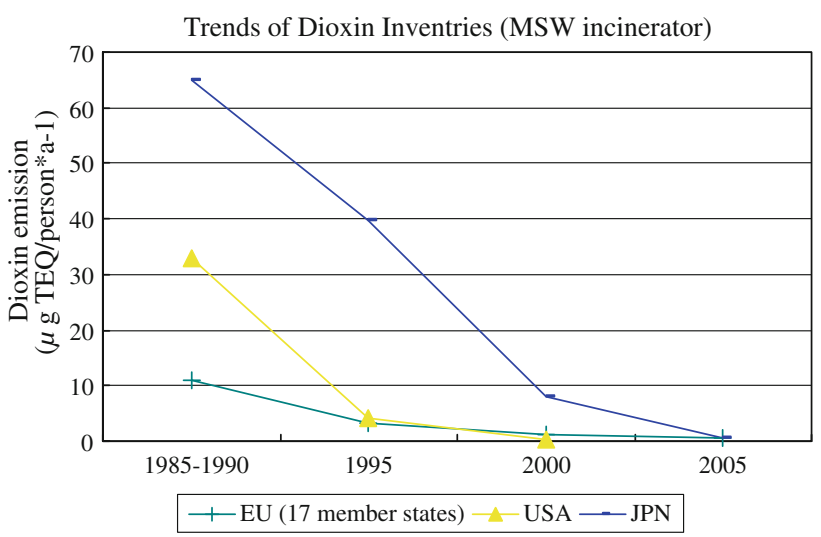

Fig. 5 Dioxin emissions from MSW incinerators in selected countries [49-55]

assuming that the amounts of glass, cans, plastic, and resins shown in the Korean waste statistics [39] are packaging wastes. The dominant components were glass and plastics (PET bottles). Glass, in particular, accounted for almost half of the total amount. This estimation places Korea between Japan $\left(22 \mathrm{~kg}\right.$ person $^{-1}$ year $\left.^{-1}\right)$ and the EU $\left(97 \mathrm{~kg}\right.$ person $^{-1}$ year $\left.^{-1}\right)$.

\section{Dioxin emissions from waste incineration}

Waste incineration is a source of dioxin emissions, and the trends in dioxin emissions per capita from waste incineration for several countries are shown in Fig. 5. In Japan, dioxin emissions exceeded $60 \mu \mathrm{g}$-TEQ person ${ }^{-1} \mathrm{year}^{-1}$ (TEQ, toxic equivalent) until strict political measures to control dioxins emissions, in the form of guidelines for the reduction of dioxins emission, were taken in 1997, at which point a large decrease in emissions occurred. In the USA, the rate of incineration had also been relatively high, (over $30 \mu \mathrm{g}$-TEQ person $^{-1}$ year $^{-1}$ ) until 1995, when countermeasures were taken and emissions rapidly decreased. In the EU, the unit dioxin emission rate had also been relatively low, $11 \mu \mathrm{g}$-TEQ person ${ }^{-1}$ year $^{-1}$, until 1995 because the incineration rate had been relatively low and the early abatement of dioxin emission (Fig. 5).

Figure 6 shows the relationship between dioxin emissions and waste incineration in Japan from 1990 to 2006 [48]. Most combustible waste was incinerated during this period, but after the Special Law on Countermeasures against Dioxins was implemented in 1999, incineration facilities were updated and a rapid decrease in emissions occurred. The rate of decrease leveled out for a few years, but dioxin emissions eventually decreased by more than $99 \%$ of the original level, driven by improved technology and the later promotion of $3 \mathrm{R}$ policies, which brought about a reduction in the amount of waste incinerated. 
Fig. 6 Dioxin emissions from waste incinerators and total amount of waste incinerated in Japan [48]

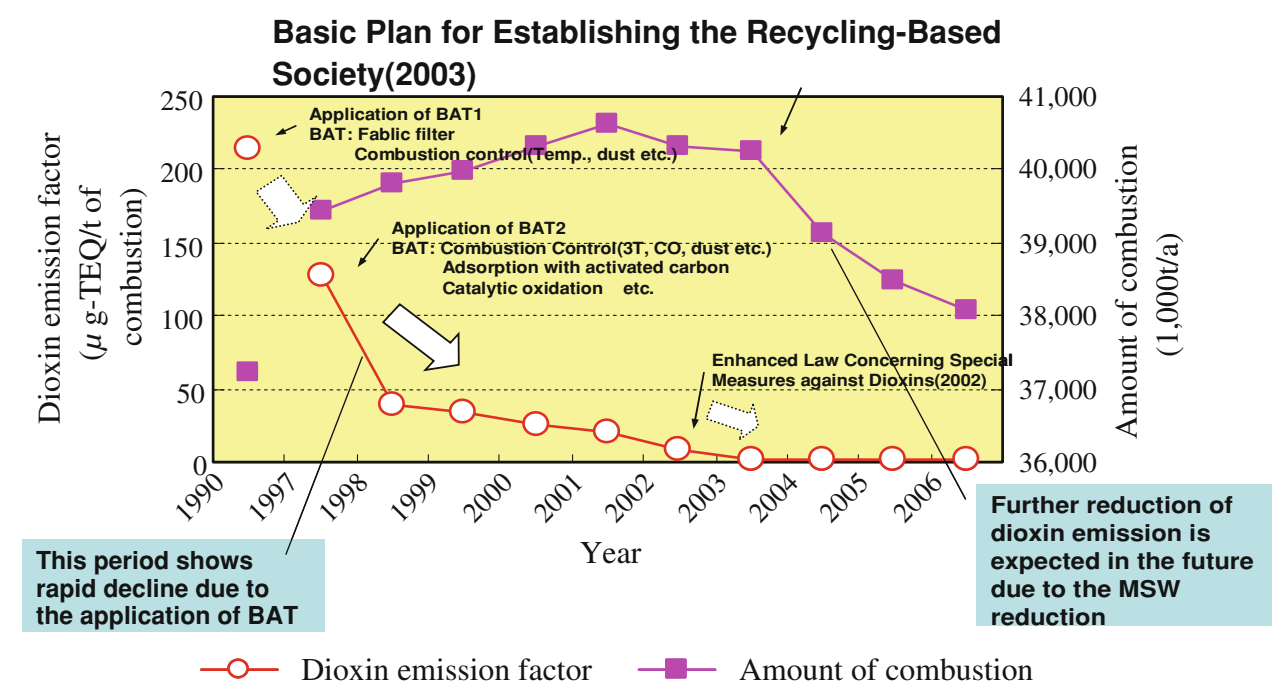

\section{Management of chemical substances and household hazardous waste}

As a basic principle, policies on managing chemical substances should be promoted in an integrated manner with $3 \mathrm{R}$ and waste management policies. The management principles of hazardous wastes and persistent chemical substances are as follows: (1) avoid the use of hazardous chemicals (clean), (2) use the substances cyclically if no adequate alternatives are available to meet the utility expected (cycle), and (3) prevent their emission into the environment and stabilize current and previously generated stocks or waste (control) [56]. In the USA, following similar principles, the Pollution Prevention Act lays down chemical management in a manner consistent with the Toxic Substances Control Act. The Pollution Prevention Act sets management policy for chemical substances and prioritizes source prevention over other measures. These include environmentally sound recycling, which is permitted only when source prevention is not possible, and waste treatment, which is permitted only when source prevention and recycling are not possible. Disposal and emission are defined as the last measures. Peeler [57] gave an example from Washington State, where a Chemical Action Plan is being undertaken concerning the management of mercury, polybrominated diphenyl ether (PBDE), and lead. Hylander [58] warned that, especially in the case of mercury, a better treatment exists than recycling, that hazardous substances are used in some cases despite existing alternatives, and that recycling becomes much easier when basic materials are not contaminated with hazardous substances.

An important issue that still remains to be solved in some countries such as Japan and the EU is the management of household hazardous waste (HHW). The European Commission Directorate of the General Environment conducted a study on HHW and published its final report in 2002 as a part of a strategy to enhance sound life-cycle management of products [59]. In the report, HHW was defined as "waste that may increase hazardousness of municipal solid waste when being landfilled, incinerated or composted," and a focus was put on the hazardous household chemical substances. Fourteen chemicals were classified as high priority for solid waste management: As, $\mathrm{Pb}, \mathrm{Cd}, \mathrm{Cr}, \mathrm{Cu}, \mathrm{Ni}, \mathrm{Hg}, \mathrm{Zn}, \mathrm{PCB}$, benzene, tetrachloroethylene, trichloroethylene, tetrachloromethane, sodium cyanide. They were identified from an emissions inventory from treatment facilities, such as landfills and incinerators. Asari et al. [60] conducted a survey of HHW possession and of the participants' experiences concerning involvement in HHW collection and recycling systems. The results indicated that providing information about the hazardousness of a product significantly increased the rate of participation in HHW collection and recycling systems. In Japan, there is a warning system for marking the presence of specific chemical substances in electrical and electronic equipment (JIS C 0950, J-MOSS) to control heavy metals such as mercury and cadmium, which are constituents of products such as personal computers, televisions, and refrigerators [61].

\section{Policy trends for waste management and prevention of GHG emissions}

The US EPA [62] reported that waste management and GHG emissions are strongly correlated. The report concluded that waste reduction and recycling promotion are considered highly important in reducing GHG emissions for the following reasons: (1) promotion of recycling will reduce energy utilization, (2) reduction of waste incineration will also reduce emissions, (3) prevention of methane gas generation by reducing the amount of landfill waste 


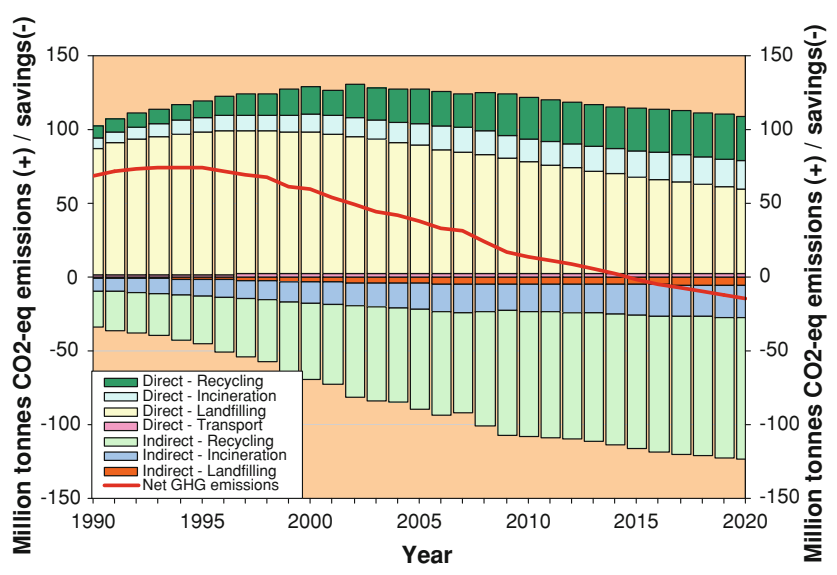

Fig. 7 GHG emissions from MSW management measures in the EU [5]

will also contribute to emissions reduction, and (4) protection of forests through paper recycling will help to maintain their carbon dioxide absorption function.

In the EU, under the Directive on Landfill of Waste (council directive 1999/31/EC), the amount of biodegradable municipal waste being landfilled is targeted to be reduced to $75 \%$ of the 1995 level in 2006, 50\% in 2009, and $35 \%$ in 2016. According to GHG emissions estimates derived from MSW management in the EU [5], waste prevention measures and recycling of biodegradable municipal waste could result in a reduction in $\mathrm{GHG}$ emissions of approximately $75 \mathrm{Mt}-\mathrm{CO}_{2}$ in 2010 and $60 \mathrm{Mt}-$ $\mathrm{CO}_{2}$ in 2020 (Fig. 7). The following assumptions were made in these estimates: the amount of MSW generated would increase from $520 \mathrm{~kg}$ person $^{-1}$ year $^{-1}$ in 2004 to $680 \mathrm{~kg}$ person $^{-1}$ year $^{-1}$ in 2020, and the ratios of management methods in 2020 would be $34 \%$ for landfill, $42 \%$ for recycling, and $23 \%$ for incineration with power generation. The emissions associated with the transport, treatment, and disposal of waste were counted as direct GHG emissions. Indirect reductions in GHG emissions were also calculated, including the use of recycled materials in place of natural resources and the substitution of power generated from fossil fuels. Better MSW management was shown to be effective in reducing GHG emissions, and the report concluded that introduction of more effective recycling as well as power generation from waste would accelerate the reduction of GHG emissions $[5]$.

\section{Conclusion}

The international comparative research on $3 \mathrm{R}$ policies showed that the directions of $3 \mathrm{R}$ policies are developed not only as simple waste management strategies but also as an approach to obtain synergistic effects with national strategies which aim at landfill prevention, procurement of resources, and reduction of GHG emissions. In addition, for circulation use of resources, it was identified that hazardous waste management is recognized as an important issue for consideration.

The first direction is the promotion of $3 \mathrm{R}$ policies to prevent final disposal in landfills, as has been done in the EU, Japan, and Korea. In these countries, the difficulty in obtaining final disposal sites has been the driving force for 3R development. In terms of organic waste, however, these countries have taken different approaches. In Japan, advanced incineration facilities have been provided at the national level, and prevention of dioxins emission has been a strong social issue as well. As a result, dioxin emissions have been greatly reduced through the use of technology and the reduction of the amount of organic waste incinerated. In the EU and Korea, however, prevention of final disposal of organic waste in landfills has been largely implemented on an administrative level, without sufficient introduction of appropriate incineration facilities. Composting of organic waste has therefore been a more important component of their $3 \mathrm{R}$ measures. The rate of incineration is less than $20 \%$ in the EU and Korea, even though thermal recovery has clearly been defined as a global warming countermeasure in these countries.

In the second direction, the aim of $3 \mathrm{R}$ policies is to secure resources in countries experiencing rapid economic growth, such as China and Vietnam. In these countries, hazardous waste management is also an important policy concern. The utilization of recycled resources has been effective in these countries because the procurement of resources has been slow relative to their economic growth. Because they need resources, these countries have been active in importing recycled resources, but that has resulted in the necessity of taking measures to prevent the import of hazardous materials that are often included in the recycled resources. Therefore, in these countries, management of hazardous wastes has been prioritized over other 3R measures, or even ranked as a higher policy objective. This is particularly true in China. Although legislation in China has been developed soundly so far, China may need to develop greater abilities to manage and implement the legislation to achieve better outcomes on $3 \mathrm{R}$ and hazardous waste management. Although there is also a legal system for hazardous waste management in Vietnam, the risk management of secondary materials carried from abroad has not been fixed. The development of $3 \mathrm{R}$ policies is inextricably associated with hazardous waste management.

In the third direction, the aim is to develop an integrated policy centered on $3 \mathrm{R}$ to obtain synergetic effects on waste management, protection of natural resources, and reduction of GHG emissions. In the USA, landfill issues have been 
relatively less urgent as compared to other countries. Even so, the USA have developed pollution restrictions for land and groundwater, as seen in the Comprehensive Environmental Response Compensation and Liability Act. The US policy currently under discussion is intended to bring about a shift in focus from waste management to an integrated and synergetic approach. This challenge is revolutionary in the sense that $3 \mathrm{R}$ as a code of conduct on waste management is given a higher policy position as part of total environmental management, although how such a paradigm shift will be accomplished is still uncertain.

Open Access This article is distributed under the terms of the Creative Commons Attribution Noncommercial License which permits any noncommercial use, distribution, and reproduction in any medium, provided the original author(s) and source are credited.

\section{References}

1. US EPA (2010) US Environmental Protection Agency 20102014 pollution prevention (P2) program strategic plan. http:// www.epa.gov/p2/pubs/docs/P2StrategicPlan2010-14.pdf. Accessed 10 Feb 2010

2. US EPA (2005) Resource conservation challenge (RCC) 2005 action plan version 1. http://www.epa.gov/epawaste/rcc/resources/ act-plan.pdf. Accessed 10 Feb 2010

3. US EPA (2008) 2009-2014 EPA strategic plan change document, for public review. http://epa.gov/ocfo/plan/pdfs/strategic_plan_ change_document_9-30-08.pdf. Accessed 10 Feb 2010

4. Directive 2008/98/EC of the European Parliament and of the Council on Waste and Repealing Certain Directives (2008) 19 November 2008. http://eur-lex.europa.eu/LexUriServ/LexUriServ. do?uri=OJ:L:2008:312:0003:0003:EN:PDF (En). Accessed 10 Feb 2010

5. Fischer C (2009) EU waste policy: development and achievements. In: International workshop on $3 \mathrm{R}$ and waste management, Kyoto City, 2009

6. European Environment Agency (2009) Diverting waste from landfill-effectiveness of waste-management policies in the European Union. http://www.eea.europa.eu/publications/divertingwaste-from-landfill-effectiveness-of-waste-management-policiesin-the-european-union/at_download/file (En). Accessed 10 Feb 2010

7. Unterseh TS (2009) Extended producer responsibility-The German experience. In: International workshop on 3R and waste management, Kyoto City, 2009

8. Hathaway R (2009) UK policy developments in support of 3R. In: International workshop on $3 \mathrm{R}$ and waste management, Kyoto City, 2009

9. Douvan AR (2009) Italian approaches on $3 R$ developments. In: International workshop on $3 \mathrm{R}$ and waste management, 2009, Kyoto City

10. Ministry of the Environment, Japan (2009) White paper on the environment

11. Ministry of Environment, Japan HP, Enactment and Amendment. http://eng.me.go.kr/content.do?method=moveContent\&menuCode =law_law_his_amendment (En). Accessed 10 Feb 2010

12. Ministry of Environment (2007) Wastes control act. http:// eng.me.go.kr/file.do?method=fileDownloader\&attachSeq=984 (En). Accessed 10 Feb 2010
13. Ministry of Environment (2008) Act on the promotion of saving and recycling of resources. http://eng.me.go.kr/file.do?method= fileDownloader\&attachSeq=1608 (En). Accessed 10 Feb 2010

14. Park JW (2009) 3R policies of Korea. Ministry of Environment HP. http://eng.me.go.kr/board.do?method=view\&docSeq=195\& bbsCode=res_mat_policy (En). Accessed 10 Feb 2010

15. Ministry of Environment (2008) Promotion of installation of waste disposal facilities and assistance, etc. to adjacent areas act. http://eng.me.go.kr/file.do?method=fileDownloader\&attachSeq= 1611 (En). Accessed 10 Feb 2010

16. Ministry of Environment (2008) Korea's 3R policy. http://search. korea.net:8080/intro_korea2008/society/02_re.html (En). Accessed 10 Feb 2010

17. Choate A (2008) Landfill analysis overview. In: EPA organics workshop, 13 May 2008. http://epa.gov/climatechange/wycd/ waste/downloads/Landfill_Briefing_final.pdf. Accessed $10 \mathrm{Feb}$ 2010

18. The Sino-Japan Friendship Centre for Environmental Protection (2008) The Recycling Economy Promotion Law. http://www.zhb. gov.cn/japan/CNE/CNE04_78.htm (Jpn). Accessed 15 Feb 2010

19. Li J (2009) Summary policy and legislative tools in promoting waste management under circular economic model in China. In: International workshop on $3 \mathrm{R}$ and waste management, Kyoto City, 2009

20. Chen M (2005) End-of-life vehicle recycling in china now and the future. JOM October 2005. http://www.springerlink.com/ content $/ 58543 \mathrm{mn} 7682747 \mathrm{~g} 7 /$ fulltext.pdf?page=1 (En). Accessed 15 Feb 2010

21. Wang Z, Obata N, Zhou W (2007) The current status and problem of automobile recycling project in China on comparison of a China-Japan. Seisaku Kagaku 15-1:83-97. http://www.ps.ritsu mei.ac.jp/assoc/policy_science/151/15107ou.pdf (in Japanese). Accessed 15 Feb 2010

22. Chi NK (2009) 3R policy development and solid waste management status in Vietnam. In: International workshop on 3R and waste management, Kyoto City, 2009

23. 59/2007/ND-CP. http://vea.gov.vn/VN/vanbanphapquy/quyphapphapluat/Pages/Nghịịinhcủachínhphủsố59.aspx (Vn). Accessed 15 Feb 2010

24. 174/2007/NĐ-CP. http://vea.gov.vn/VN/vanbanphapquy/quyphapphapluat/Pages/Nghịđịnh1742007củachínhphủvềphíBVMTđ ốivớiCTR.aspx (Vn). Accessed 15 Feb 2010

25. 43/2007/QĐ-BYT. http://vea.gov.vn/VN/vanbanphapquy/quyphapphapluat/Pages/Quyêtđịnhcủabộtrưởngbộytếsố43.aspx (Vn). Accessed 15 Feb 2010

26. 23/2006/QĐ-BTNMT. http://vea.gov.vn/VN/vanbanphapquy/ quyphapphapluat/Pages/Quyếtđịnh.aspx. Accessed 15 Feb 2010

27. Vietnam Government (2009) National strategy on integrated SWM to 2025 and vision to 2050 Vietnam (2149/QD-TTg). http:// vea.gov.vn/VN/vanbanphapquy/Pages/ChiếnlượcQuốcgiavếquảnlýtổnghợpchấtthảirắnđếnnăm2025,tầmnhìnđếnnăm2050. aspx (Vn). Accessed 15 Feb 2010

28. Vietnam Environment Administration HP. http://vea.gov.vn/ VN/Pages/trangchu.aspx (Vn). Accessed 15 Feb 2010

29. The Sino-Japan Friendship Centre for Environmental Protection (2005) Law of the People's Republic of China on the Prevention and Control of Environmental Pollution by Solid Waste. http://www. zhb.gov.cn/japan/CNE/CNE04_14.htm (Jpn). Accessed 15 Feb 2010

30. Wejchert J (2009) EU policies on the sustainable management of resources. In: International workshop on $3 \mathrm{R}$ and waste management, Kyoto City, 2009

31. Oh GJ (2009) 3R and waste management policy and outcome in Korea. In: International workshop on $3 \mathrm{R}$ and waste management, Kyoto City, 2009

32. US EPA (2006) 2006-2011 EPA strategic plan. http://www. epa.gov/ocfo/plan/2006/entire_report.pdf. Accessed 10 Feb 2010 
33. US EPA (2004) Resource conservation challenge strategic planwhat can you save tomorrow? Five year plan. http://www.epa. gov/osw/rcc/resources/strat-plan.pdf. Accessed 10 Feb 2010

34. Yoshida H (2009) Japan's experiences of policy developments on $3 \mathrm{R}$ and waste management. In: International workshop on $3 \mathrm{R}$ and waste management, Kyoto City, 2009

35. Ministry of Environment (2007) Resource recirculation policy of Korea. http://search.korea.net:8080/intro_korea2008/society/02_re. html (En). Accessed 10 Feb 2010

36. US EPA (2008) MSW characterization methodology, municipal solid waste (MSW) in the United States. US EPA HP. http:// www.epa.gov/epawaste/nonhaz/municipal/pubs/06numbers.pdf. Accessed 10 Feb 2010

37. Ministry of the Environment (2009) Basic plan for establishing a Material Cycles Society (2008 version)

38. US EPA (2009) Municipal solid waste generation, recycling, and disposal in the United States: facts and figures for 2008, municipal solid waste (MSW) in the United States. US EPA HP. http://www.epa.gov/waste/nonhaz/municipal/pubs/msw2008rpt. pdf. Accessed 10 Feb 2010

39. Ministry of Environment (2009) 2008 Waste generation and treatment. http://library.me.go.kr/dliwebme/components/searchir/ detail/popup.aspx?cid=199849 (Ko). Accessed 15 Feb 2010

40. US EPA (2009) Municipal solid waste generation, recycling, and disposal in the United States: detailed tables and figures for 2008, municipal solid waste (MSW) in the United States. US EPA HP. http://www.epa.gov/waste/nonhaz/municipal/pubs/msw2008data. pdf. Accessed 10 Feb 2010

41. European Commission (2009) Eurostat, Municipal waste by type of treatment. http://epp.eurostat.ec.europa.eu/portal/page/portal/ product_details/dataset?p_product_code=TSIEN130. Accessed 20 Mar 2010

42. Ministry of the Environment Japan (2009) Field survey on municipal waste management

43. Ministry of the Environment, Korea (2009) 2009 Environmental statistics yearbook. http://library.me.go.kr/dliwebme/components/ searchir/detail/popup.aspx?cid=198771 (Ko, En). Accessed 15 Feb 2010

44. European Commission (2009) Eurostat Data Centre on waste. http:// epp.eurostat.ec.europa.eu/portal/page/portal/waste/documents/ Packaging_2009_11_26_publication.xls; http://ec.europa.eu/ environment/waste/packaging/data.htm. Accessed 20 Mar 2010

45. Department of Resources Recycling and Recovery (2010) CalRecycle. http://www.calrecycle.ca.gov/. Accessed 10 Feb 2010

46. Ministry of the Environment (2008) Summary of field survey on use and emission of containers and packaging waste. http://www. env.go.jp/recycle/yoki/c_2_research/research_03.html. Accessed 10 Feb 2010

47. EEA (2010) CSI 017-generation and recycling of packaging waste-assessment. http://themes.eea.europa.eu/IMS/IMS/ISpecs/
ISpecification20041007131825/IAssessment1234521865625/view_ content. Accessed 20 Mar 2010

48. Sakai S, Ota S, Kondo Y (2009) Unintentional POPs inventories in East Asian countries. In: 3rd workshop on reduction of unintentional POPs in East Asian countries, 1st-2nd October 2009

49. Quass U, Fermann M, Bröker G (2000) EU dioxin emission inventory stage II, vol 1

50. Quass U, Fermann M, Bröker G (2000) EU dioxin emission inventory stage II, vol 3

51. DEFRA (2007) United Kingdom of Great Britain and Northern Ireland, National Implementation Plan for the Stockholm Convention on Persistent Organic Pollutants. http://www.pops.int/ documents/implementation/nips/submissions/UKNational\%20 Implementation\%20Plan_Defra_UKNIP_V5.pdf. Accessed 20 Mar 2010

52. US EPA (2006) An inventory of sources and environmental releases of dioxin-like compounds in the US for the years 1987, 1995, and 2000 (EPA/600/P-03/002f, final report, November 2006)

53. Ministry of the Environment (2008) Waste treatment in Japan (fiscal year 2006)

54. Ministry of the Environment (2008) Emission inventories of dioxins

55. Population Division of the Department of Economic and Social Affairs of the United Nations Secretariat (2010) World population prospects: the 2008 revision. http://esa.un.org/unpp. Accessed 23 Feb 2010

56. Sakai S (2000) Material cycles science concept. Environ Sci Pollut Res 7(4):225-232

57. Peeler MV (2009) Reducing toxic threats and waste management control. In: International workshop on $3 \mathrm{R}$ and waste management, Kyoto City, 2009

58. Hylander LD (2009) Swedish approaches on 3R developments. In: International workshop on 3R and waste management, Kyoto City, 2009

59. European Commission Directorate-General Environment (2002) Study on hazardous household waste (HHW) with a main emphasis on hazardous household chemicals (HHC)-final report, WRc: CO 5089-2 (2002)

60. Asari M (2009) Perspectives on household hazardous waste management. In: International workshop on $3 \mathrm{R}$ and waste management, Kyoto City, 2009

61. Central Environmental Council, Division of Recycling-Based Society Planning (50th) (2009) Concept arrangement of generating control and result of estimate on the effect by cyclic use

62. US EPA (2003) Wastewise: climate benefits from reducing waste (program snapshot). http://www.epa.gov/waste/nonhaz/municipal/ pubs/ghg/clim-ww.pdf 